\title{
Epithelial-Mesenchymal Transition in Non Small-cell Lung Cancer
}

\author{
NIKOLAOS TSOUKALAS ${ }^{1 *}$, ELENI ARAVANTINOU-FATOROU ${ }^{2 *}$, MARIA TOLIA $^{3}$, CONSTANTINOS GIAGINIS $^{4}$, \\ MICHAIL GALANOPOULOS ${ }^{5}$, MARIA KIAKOU ${ }^{5}$, IOANNIS D. KOSTAKIS ${ }^{5}$, EUGENE DANA ${ }^{4}$, \\ IOANNIS VAMVAKARIS ${ }^{4}$, ATHANASIOS KOROGIANNOS ${ }^{4}$, EVANGELOS TSIAMBAS ${ }^{5}$, \\ NIKOLAOS SALEMIS ${ }^{5}$, GEORGE KYRGIAS ${ }^{3}$, ANDREAS KARAMERIS ${ }^{6}$ and STAMATIOS THEOCHARIS ${ }^{4}$ \\ Departments of ${ }^{1}$ Oncology and ${ }^{6}$ Pathology, Veterans Hospital (NIMTS), Athens, Greece; \\ ${ }^{2} 251$ Air Force Hospital, Athens, Greece; \\ ${ }^{3}$ Department of Radiotherapy-Radiation Oncology, Faculty of Medicine, School of Health Sciences, \\ University of Thessaly, Larissa, Greece; \\ ${ }^{4}$ First Department of Pathology, Medical School, University of Athens, Athens, Greece; \\ ${ }^{5} 401$ General Military Hospital, Athens, Greece
}

\begin{abstract}
Background/Aim: Lung cancer is the first cause of cancer related deaths in both males and females. Epithelialmesenchymal transition (EMT) is a reversible process by which epithelial cells transform to mesenchymal stem cells by losing their cell polarity and cell-to-cell adhesion, gaining migratory and invasive properties. High levels of E-cadherin are expressed in epithelial cells, whereas mesenchymal cells express high levels of $N$-cadherin, fibronectin and vimentin. The aim of this study was to evaluate the correlation between E-cadherin and vimentin expression and their clinical significance in non-small cell lung cancer (NSCLC). Materials and Methods: The immunohistochemical expression of E-cadherin, vimentin and Ki-67 was performed on tissue microarrays from NSCLC specimens obtained from 112 newly-diagnosed cases and were studied using classical pathological evaluation. Associations between E-cadherin, vimentin and Ki-67 expression, clinicopathological variables and survival were analyzed. In all cases, a value of $p \leq 0.05$ was considered significant. Results: Low E-cadherin expression was significantly correlated with tumor necrosis $(p=0.019)$. Moreover, there was a trend for
\end{abstract}

This article is freely accessible online.

*These Authors contributed equally to this study.

Correspondence to: Dr. Nikolaos Tsoukalas, MD, M.Sc., Ph.D., Medical Oncologist, M.Sc. in Bioinformatics, Consultant at Department of Oncology, Veterans Hospital (NIMTS), Gennimata N.10-12 Ampelokipi 11524 Athens, Greece. Mobile: +30 6977366056, e-mail: tsoukn@yahoo.gr

Key Words: E-Cadherin, vimentin, epithelial mesenchymal transition (EMT), non-small-cell lung cancer (NSCLC), biomarker, prognosis. correlation between high E-cadherin expression and better overall survival (hazard ratio $=1.02$, and $95 \%$ confidence interval=0.45-1.87, $p=0.091$ ). There was also a significant negative correlation between vimentin expression and overall survival (hazard ratio=1.13, and 95\% confidence interval=0.78-1.65, $p=0.026)$. Additionally, there was a significant negative correlation between vimentin expression and grade I tumors $(p=0.031)$. Finally, a positive correlation trend between vimentin expression and Ki-67 was found $(p=0.073)$. Conclusion: High E-cadherin and low vimentin expression correlate with better prognosis and overall survival.

Lung cancer is the first cause of cancer-related deaths in both males and females. It is a fatal disease and most patients with lung cancer will die of their disease (1). Two main types of lung cancer exist: non-small-cell lung cancer (NSCLC) accounting for $85-90 \%$ of lung cancer cases, and small-cell lung cancer (SCLC), whose incidence seems to have decreased over the past decades (2). The current therapeutic approach for lung cancer includes surgical tumor removal, platinum-based chemotherapy, targeted therapy, immunotherapy and radiation therapy. Improvements in clinical and molecular understanding of the disease have resulted in novel therapeutic approaches. Multiple genetic and epigenetic abnormalities results in both oncogene activation [epidermal growth factor receptor $(E G F R)$ and anaplastic lymphoma kinase $(A L K)]$ and inactivation of tumor-suppressor genes [transcription factor (p53) and retinoblastoma protein (RB)] (3). Moreover, angiogenesis seems to play an important role in the process of invasion and metastasis in lung cancer (4). Other molecular and cellular processes of lung cancer include genomic instability, escape from apoptosis, cell immortalization, abnormalities in immune response and epithelial-mesenchymal transition (EMT) (5-9). 
EMT is a reversible process by which epithelial cells transform to mesenchymal stem cells by losing their cell polarity and cell-to-cell adhesion, gaining migratory and invasive properties. It is the step by which an early tumor stage converts to an invasive one (9-11). Subsequently, the opposite process occurs: mesenchymal-epithelial transition (MET). For EMT transformation, epithelial cancer cells express mesenchymal proteins such as vimentin, fibronectin, $\mathrm{N}$ cadherin and matrix metalloproteases, and become mesenchymal cells, ready for migration (12-14). During MET, cancer cells repossess the epithelial phenotype and reduce their expression of mesenchymal proteins including vimentin (15).

Vimentin, an important marker for EMT, is an intermediate filament type III, expressed in various non epithelial cells, particularly in mesenchymal ones (16). It is found in the cytoplasm and its role is to stabilize the cytoskeleton with microfilaments and microtubules (17-19). Vimentin is overexpressed in epithelial cancer types such as prostate, breast and lung cancer, while high expression levels are associated with poor prognosis (20). On the other hand, high E-cadherin levels are expressed in epithelial cells. E-Cadherin is a transmembrane protein that plays an important role in cell adhesion. More precisely, the extracellular domain of E-cadherin is responsible for cell adhesion and the intracellular domain interacts with catenin and connects to the actin cytoskeleton (21-22). Low Ecadherin expression has been observed in cancer cells and is related to advanced disease (21-24).

The aim of this study was to evaluate the correlation between E-cadherin and vimentin expression levels and clinicopathological variables and their clinical significance in NSCLC.

\section{Materials and Methods}

Study patients. One hundred and twelve patients (93 men and 19 women) diagnosed with newly diagnosed primary NSCLC were enrolled in this study. Disease diagnosis was based on pathological examination. Their medical records were reviewed in order to collect the following parameters: age, gender, performance status, smoking habit, pathological data (histological type, grade, lymphovascular invasion, inflammation, necrosis and fibrosis), disease stage (TNM according to the seventh edition of AJCC) (25) and overall survival. Baseline characteristics of the patients enrolled are presented in Table I that was published in one of our previous studies (26). The mean age of patients analyzed was 63.6 years and the median age 64 years. The majority of cases were adenocarcinomas $(52.7 \%)$. The mean and median monitoring duration were 27.5 and 17.5 months, respectively. All the participants gave their written informed consent to this study and this study conforms to the Declaration of Helsinki.

Tissue microarrays and immunohistochemistry. We collected tissues by sampling one representative tissue core, $1 \mathrm{~mm}$ in diameter chosen from each formalin-fixed, paraffin-embedded tumor specimen (2730). The sections of tissue microarrays (TMAs) were dewaxed using xylene and rehydrated through graded alcohols. During the process,
Table I. Demographic clinical and pathological features of patients $(n=112)(26)$.

\begin{tabular}{lc}
\hline Characteristic & Value \\
\hline Mean age \pm SD (range), years & $63.6 \pm 10.6(25-83)$ \\
Gender, n (\%) & $93(83 \%)$ \\
Male & $19(17 \%)$ \\
Female & \\
Smoking, n (\%) & $102(91.1 \%)$ \\
Yes & $10(8.9 \%)$ \\
No & \\
Alcohol, n (\%) & $64(57.1 \%)$ \\
Yes & $48(42.9 \%)$ \\
No & \\
Performance status, n $(\%)$ & $32(28.6 \%)$ \\
0 & $63(56.3 \%)$ \\
1 & $17(15.2 \%)$ \\
2 & \\
Histological type & $59(52.7 \%)$ \\
Adenocarcinoma & $37(33 \%)$ \\
Squamous & $10(8.9 \%)$ \\
Large cell & $6(5.4 \%)$ \\
Other type & \\
\hline
\end{tabular}

a blocking reagent (Snipper, Biocare Medical, Walnut Creek, CA, USA) was used to block non-specific antibody. Three binding targeted mouse monoclonal antibodies were then used to detect Ecadherin (Dako, Glostrup, Denmark), vimentin (Abcam, Cambridge, UK) and Ki-67 (Dako) expression. Antigen retrieval was performed by microwaving slides for $15 \mathrm{~min}$ at $720 \mathrm{~W}$ in $10 \mathrm{mM}$ citrate buffer (pH 6.0) and then incubating them for $1 \mathrm{~h}$ at room temperature with the primary antibodies. The dilutions for E-cadherin, vimentin, and Ki-67 were 1:100, 1:200 and 1:100 in phosphate-buffered saline (PBS), respectively. The samples were washed with PBS (three times), incubated with biotinylated linking reagent (Biocare Medical, Walnut Creek, CA, USA) and then with peroxidase-conjugated streptavidin label (Biocare Medical, DAB; Sigma, Saint Louis, MO, USA). Furthermore, the primary antibody was omitted and substituted by an irrelevant anti-serum antibody in negative controls. As positive controls, tumor tissue sections with known high Ecadherin, vimentin and Ki-67 expression were used (normal human urothelium, normal human fibroblasts and normal human tonsil, respectively). The evaluation of immunohistochemistry was carried out by two independent pathologists using classical pathology methods (semi-quantitatively evaluation). Particularly, two parameters were evaluated, the intensity of staining (weak or diffuse while background staining considered negative) and the percentage (\%) of tumor cells stained (both membranous and cytoplasmic for E-cadherin and vimentin while nuclear for Ki-67 positivity).

Statistical analysis. Correlations of E-cadherin, vimentin and Ki-67 expression levels in NSCLC tissue with patient characteristics (clinicopathological variables) were identified by using chi-square test. Kaplan-Meier method was used in order to create the survival curves and any differences detected were compared with the log-rank-test. Correlation between potential prognostic marker and overall survival was analyzed by a Cox proportional-hazard regression model. Cox regression analysis was conducted at both univariate and multivariate 
Table II. Association between the expression of E-cadherin and clinicopathological data of patients $(n=112)$.

\begin{tabular}{|c|c|c|c|}
\hline & \multicolumn{2}{|c|}{ E-Cadherin } & \multirow[b]{2}{*}{$p$-Value* } \\
\hline & High & Low & \\
\hline Age & & & 0.448 \\
\hline$<64$ Years & 27 & 30 & \\
\hline$\geq 64$ Years & 30 & 25 & \\
\hline Gender & & & 0.179 \\
\hline Male & 50 & 43 & \\
\hline Female & 7 & 12 & \\
\hline Smoker & & & 0.199 \\
\hline Yes & 54 & 48 & \\
\hline No & 3 & 7 & \\
\hline Alcohol use & & & 0.851 \\
\hline Yes & 32 & 32 & \\
\hline No & 25 & 23 & \\
\hline PS & & & 0.641 \\
\hline 0 & 16 & 16 & \\
\hline 1 & 34 & 29 & \\
\hline 2 & 7 & 10 & \\
\hline Histological type & & & 0.262 \\
\hline Adenocarcinoma & 29 & 30 & \\
\hline Squamous & 16 & 21 & \\
\hline Large cell & 7 & 3 & \\
\hline Carcinoid & 2 & 0 & \\
\hline NSCLC & 3 & 1 & \\
\hline Grade & & & 0.116 \\
\hline I & 10 & 7 & \\
\hline II & 28 & 19 & \\
\hline III & 19 & 29 & \\
\hline Lymphovascular invasion & & & 0.192 \\
\hline Yes & 11 & 17 & \\
\hline No & 46 & 38 & \\
\hline Inflammation & & & 0.361 \\
\hline Yes & 10 & 14 & \\
\hline No & 47 & 41 & \\
\hline Necrosis & & & 0.019 \\
\hline Yes & 29 & 37 & \\
\hline No & 28 & 18 & \\
\hline Fibrosis & & & 0.071 \\
\hline Yes & 13 & 5 & \\
\hline No & 44 & 50 & \\
\hline $\mathrm{T}$ & & & 0.487 \\
\hline T1 & 12 & 7 & \\
\hline $\mathrm{T} 2$ & 31 & 29 & \\
\hline T3 & 9 & 14 & \\
\hline $\mathrm{T} 4$ & 5 & 5 & \\
\hline $\mathrm{N}$ & & & 0.194 \\
\hline No & 15 & 8 & \\
\hline N1 & 28 & 24 & \\
\hline $\mathrm{N} 2$ & 13 & 22 & \\
\hline N3 & 1 & 1 & \\
\hline M & & & 0.301 \\
\hline M0 & 55 & 50 & \\
\hline M1a & 0 & 2 & \\
\hline M1b & 2 & 3 & \\
\hline Stage & & & 0.496 \\
\hline I & 6 & 4 & \\
\hline II & 27 & 22 & \\
\hline III & 21 & 24 & \\
\hline IV & 2 & 5 & \\
\hline
\end{tabular}

NSCLC: Non-small-cell lung cancer; PS: performance status. ${ }^{*}$ Chi square test.

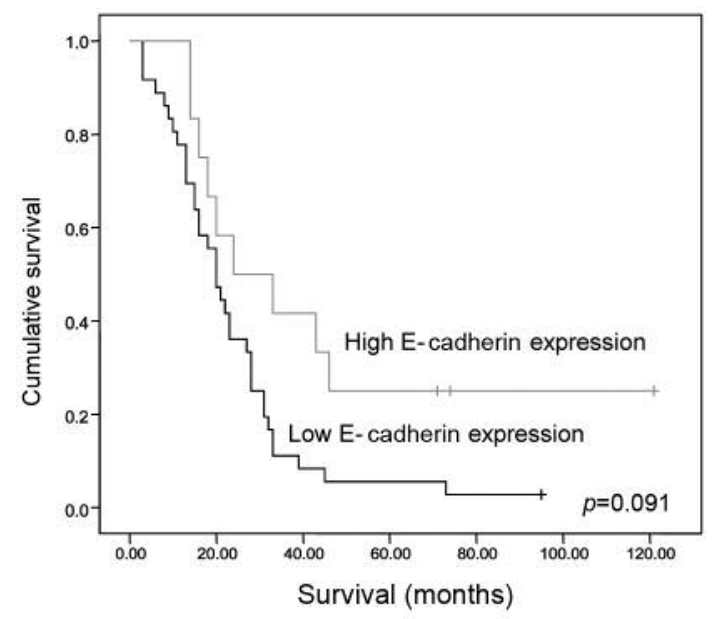

Figure 1. Kaplan-Meier survival analysis according to E-cadherin expression.

levels. In all cases, an alpha level of $<0.05$ was considered significant. SPSS program for Windows performed the statistical analysis (version 13.0; SPSS Inc., Chicago, IL, USA).

\section{Results}

The median expression value was used to separate patients into two groups according to whether immunohistochemical E-cadherin expression was above (high expression) or below (low expression) the median value. E-Cadherin expression was high in 57 patients $(57 / 112,51 \%)$ and low in 55 patients (55/112, 49\%) (Table II). Notably, low E-cadherin expression was significantly correlated with tumor necrosis $(p=0.019)$. On the contrary, E-cadherin expression was not significantly associated with age, gender, smoking status, alcohol use, performance status (PS), histological type, grade, stage of disease, primary tumor $(\mathrm{T})$, lymph nodes $(\mathrm{N})$, metastasis (M), lymphovascular invasion, inflammation or fibrosis (Table II). There was no correlation between E-cadherin and $\mathrm{Ki}-67$. We found a trend for positive correlation between high E-cadherin expression and overall survival $(\mathrm{HR}=1.02$, 95\% CI=0.45-1.87, $p=0.091$ ) (Figure 1).

Similarly, the median expression value was used to separate patients into two groups according to immunohistochemical vimentin expression (Table III). There was a significant negative correlation between vimentin expression and grade I tumors $(p=0.031)$. Vimentin expression was not significantly associated with age, gender, smoking status, alcohol use, performance status (PS), histological type, stage of disease, primary tumor (T), lymph nodes $(\mathrm{N})$, metastasis $(\mathrm{M})$, lymphovascular invasion, inflammation, necrosis or fibrosis (Table III). Also, there was a trend for positive correlation between vimentin expression 
Table III. Association between the expression of vimentin and clinicopathological data of patients $(n=112)$.

\begin{tabular}{|c|c|c|c|}
\hline & \multicolumn{2}{|c|}{ Vimentin } & \multirow[b]{2}{*}{$p$-Value* } \\
\hline & High & Low & \\
\hline Age & & & 0.322 \\
\hline$<64$ Years & 17 & 40 & \\
\hline$\geq 64$ Years & 22 & 33 & \\
\hline Gender & & & 0.798 \\
\hline Male & 33 & 60 & \\
\hline Female & 6 & 13 & \\
\hline Smoker & & & 0.737 \\
\hline Yes & 35 & 67 & \\
\hline No & 4 & 6 & \\
\hline Alcohol use & & & 0.690 \\
\hline Yes & 21 & 43 & \\
\hline No & 18 & 30 & \\
\hline PS & & & 0.416 \\
\hline 0 & 9 & 23 & \\
\hline 1 & 22 & 41 & \\
\hline 2 & 8 & 9 & \\
\hline Histological type & & & 0.375 \\
\hline Adenocarcinoma & 21 & 38 & \\
\hline Squamous & 13 & 24 & \\
\hline Large cell & 5 & 5 & \\
\hline Carcinoid & 0 & 2 & \\
\hline NSCLC & 0 & 4 & \\
\hline Grade & & & 0.017 \\
\hline I & 2 & 15 & \\
\hline II & 14 & 33 & \\
\hline III & 23 & 25 & \\
\hline Lymphovascular invasion & & & 1.00 \\
\hline Yes & 10 & 18 & \\
\hline No & 29 & 55 & \\
\hline Inflammation & & & 0.473 \\
\hline Yes & 10 & 14 & \\
\hline No & 29 & 59 & \\
\hline Necrosis & & & 0.546 \\
\hline Yes & 25 & 41 & \\
\hline No & 14 & 32 & \\
\hline Fibrosis & & & 0.178 \\
\hline Yes & 9 & 9 & \\
\hline No & 30 & 64 & \\
\hline $\mathrm{T}$ & & & 0.074 \\
\hline $\mathrm{T} 1$ & 3 & 16 & \\
\hline $\mathrm{T} 2$ & 27 & 33 & \\
\hline T3 & 7 & 16 & \\
\hline $\mathrm{T} 4$ & 2 & 8 & \\
\hline $\mathrm{N}$ & & & 0.771 \\
\hline No & 6 & 17 & \\
\hline N1 & 19 & 33 & \\
\hline N2 & 13 & 22 & \\
\hline N3 & 1 & 1 & \\
\hline M & & & 0.441 \\
\hline M0 & 38 & 67 & \\
\hline M1a & 0 & 2 & \\
\hline M1b & 1 & 4 & \\
\hline Stage & & & 0.176 \\
\hline I & 1 & 9 & \\
\hline II & 20 & 29 & \\
\hline III & 17 & 28 & \\
\hline IV & 1 & 6 & \\
\hline
\end{tabular}

NSCLC: Non-small-cell lung cancer; PS: performance status. *Chi-square test.

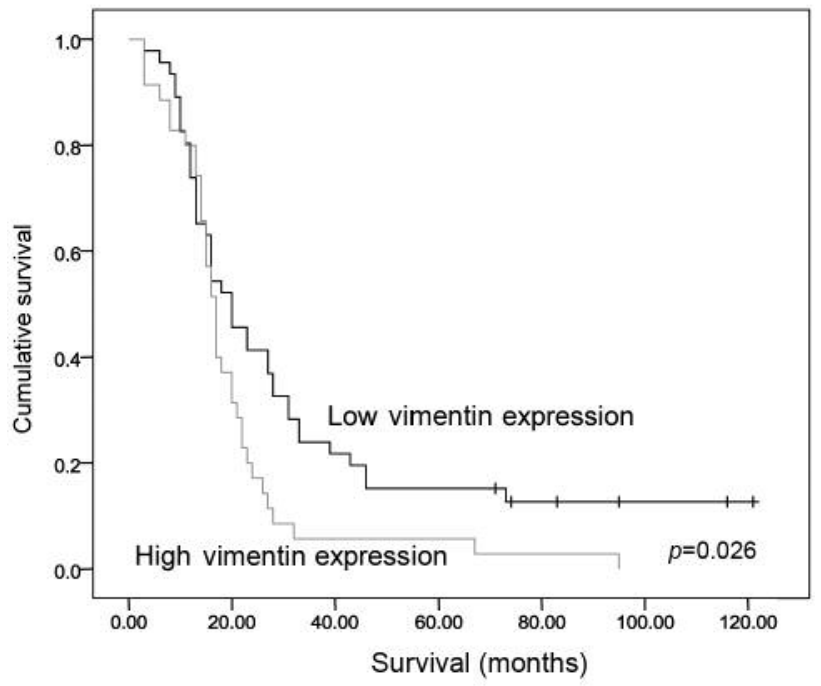

Figure 2. Kaplan-Meier survival analysis according to vimentin expression.

and Ki-67 $(p=0.073)$. Finally, there was a significant negative correlation between vimentin expression and survival (hazard ratio $=1.13,95 \%$ confidence interval $=0.78$ $1.65, p=0.026$ ) (Figure 2).

\section{Discussion}

A crucial step in cancer progression is the migration of cancer cells through close lying tissues and vessels to distant tissues. EMT is a mechanism mediating this process (2). As epithelial cancer cells decrease their expression of epithelial proteins, lose cell-cell adhesion and express mesenchymal proteins, the cytoskeleton is remodeled (9-11). Many studies have investigated EMT in different cancer types (5-14). In the present study, we analyzed the expression of the mesenchymal marker vimentin and of the epithelial cell marker E-cadherin in tumor cells of patients with NSCLC in order to correlate these proteins with clinicopathological parameters as well as overall survival.

The most important conclusions of this study was to point out are the significant negative correlation between vimentin expression and overall survival (hazard ratio $=1.13,95 \%$ confidence interval $=0.78-1.65, p=0.026$ ) and the trend for correlation between higher E-cadherin expression and better overall survival (hazard ratio $=1.02,95 \%$ confidence interval $=0.45-1.87, p=0.091$ ). Higher expression of vimentin in tumor samples implies a more aggressive type of tumor and a worse overall survival. These data confirm the role of EMT process in the evaluation of lung cancer and are similar to other studies in several cancer types including NSCLC cell lines, colorectal, thyroid, head and neck and bladder cancer (31-36). 
Moreover, low E-cadherin expression was significantly correlated with tumor necrosis $(p=0.019)$. It is known that necrosis is an independent risk factor in survival and tumor recurrence in patients with NSCLC (37), implying that Ecadherin expression is associated with favorable prognosis. Also according to our results, there was a significant negative correlation between vimentin expression and grade I tumors $(p=0.031)$. These findings suggest that low expression of vimentin is related to well-differentiated tumors. These data are similar to those of the literature as vimentin expression is associated with an aggressive tumor phenotype (38-40). ECadherin and vimentin expression were not significantly associated with other clinicopathological parameters in this study.

A variety of markers has been studied or is under investigation in NSCLC in order to thoroughly understand disease progression $(26,41-43)$. EMT is one of the pathways for NSCLC progression. In particular, there are data suggesting the involvement of EMT not only in the prognosis of patients with NSCLC but also in the response to specific treatments such as anti-EGFR therapies that are used nowadays for this tumor type (44). Additionally, there are data regarding the possibly implication of EMT in response to treatment with ALK inhibitors among patients with EML4-ALK NSCLC (45). Finally, there are some data referring to possible ways for reversion of the EMT in NSCLC, such as blocking muscarinic receptor signaling in vitro and in vivo, indicating that probably non-neuronal acetylcholine promotes EMT partially through activation of muscarinic receptor M2R (46).

Inevitably, we recognize that there are some limitations to our study. This was a small study with 112 tissue samples with NSCLC. Another limitation is the fact that the evaluation of vimentin and E-cadherin expression were done using only immunohistochemistry. Besides that, apart from E-cadherin and vimentin, there are other markers of EMT phenomenon such as $\mathrm{N}$-cadherin and fibronectin which could be studied. Therefore, more and larger studies are required to reinforce these data and the role of EMT in NSCLC.

In conclusion, there are data suggesting that EMT plays an important role in carcinogenesis and metastasis. In the past decades, an increased number of studies have shown that EMT is associated with poor prognosis in different tumor types including NSCLC. Our data strengthen these data. Further investigation of EMT in NSCLC is needed in order to elucidate its role in the process of cancer development and metastasis. Possibly, in the future detection of EMT could be used not only for a better stratification of patients with NSCLC concerning their prognosis but also for the development of new therapeutic approaches.

\section{Conflicts of Interest}

No potential conflicts of interest exist. No financial support was granted.

\section{References}

1 Siegel R, Miller K and Jemal A: Cancer statistics 2016. CA Cancer J Clin 66: 7-30, 2016.

2 Duffy MJ, McGowan PM and Gallagher WM: Cancer invasion and metastasis: changing views. J Pathol 214: 283-293, 2008.

3 Zöchbauer-MüllerS, Gazdar AF and Minna JD: Molecular Pathogenesis of Lung Cancer. Annu Rev Physiol 64: 681-708, 2002.

4 Ferrara N: VEGF: an update on biological and therapeutic aspects. Curr Opin Biotechnol 11: 617-624, 2000.

5 Sato M, Shames DS, Gazdar AF and Minna JD: A translational view of the molecular pathogenesis of lung cancer. $J$ ThoracOncol 2(4): 327-343, 2007.

6 Bruin EC, McGRanahan N, Mitter R, Salm M, Wedge DC, Yates L, Jamal-Hanjani M, Shafi S, Murugaesu N, Rowan AJ, Gronroos E, Muhammad MA, Horswell S, Gerlinger M, Varela I, Jones D, Marshall J, Voet T, Van Loo P, Rassl DM, Rintoul RC, Janes SM, Lee SM, Forster M, Ahmad T, Lawrence D, Falzon M, Capitanio A, Harkins TT, Lee CC, Tom W, Teefe E, Chen SC, Begum S, Rabinowitz A, Philimore B, Spencer-Dene B, Stamp G, Szallasi Z, Matthews N, Stewart A, Campbell P and Swanton C: Spatial and temporal diversity in genomic instability processes defines lung cancer evolution. Science 6206(346): 251-256, 2014.

7 Codony-Serva J and Rosell R: Cancer stem cells and immunoresistance: clinical implications and solutions. Transl Lung Cancer Res 4(6): 689-703, 2015.

8 Brahmer JR and Pardoll DM: Immune checkpoint inhibitors: making immunotherapy a reality for the treatment of lung cancer. Cancer Immunol Res 85: 1-8, 2013.

9 KangY and Massague J: Epithelial-mesenchymal transitions: twist in development and metastasis. Cell 118: 277-279, 2004.

10 Iwano M, Plieth D, Danoff TM, Xue C, Okada H and Neilson: Evidence that fibroblasts derive from epithelium during tissue fibrosis. J Clin Invest 110: 341-350, 2002.

11 Yilmaz M, Christofori G and Lehembre F: Distinct mechanisms of tumor invasion and metastasis. Trends Mol Med 13: 535-541, 2007.

12 Soltermann A, Tischler V, Arbogast S, Braun J, Probst-Hensch N, Weder W, Moch H and Kristiansen G: Prognostic significance of epithelial-mesenchymal and mesenchymal-epithelial transition protein expression in non-small cell lung cancer. Clin Cancer Res 14: 7430-7438, 2008.

13 Larue L and Bellacosa A: Epithelial-mesenchymal transition in development and cancer: role of phosphatidylinositol 3 kinase/AKT pathways. Oncogene 24: 7443-54, 2005.

14 Garber K: Epithelial-to-mesenchymal transition is important to metastasis, but questions remain. J Natl Cancer Inst 100: 232239, 2008.

15 Chaffer CL, Brennan JP, Slavin JL, Blick T, Thompson EW and Williams ED: Mesenchymal-to-epithelial transition facilitates bladder cancer metastasis: role of fibroblast growth factor receptor-2. Cancer Res 66(23): 11271-11278, 2006.

16 Thiery JP: Epithelial-mesenchymal transitions in tumour progression. Nat Rev Cancer 2(6): 442-454, 2002.

17 Hesse M, Magin TM and Weber K: Genes for intermediate filament proteins and the draft sequence of the human genome: novel keratin genes and a surprisingly high number of pseudogenes related to keratin genes 8 and 18. J Cell Sci 114: 2569-2575, 2001. 
18 Katsumoto T, Mitsushima A and Kurimura T: The role of the vimentin intermediate filaments in rat $3 \mathrm{Y} 1$ cells elucidated by immunoelectron microscopy and computer-graphic reconstruction. Biol Cell 68(2): 139-146, 1990.

19 Green KJ, Bohringer M, Gocken T and Jones JC: Intermediate filament associated proteins. Adv Protein Chem 70: 143-202, 2005.

20 Satelli A and Li S: Vimentin in cancer and its potential as a molecular target for cancer therapy. Cell Mol Life Sci 68(18): 3033-3046, 2011.

21 Oka H, Shiozaki H, Kobayashi K, Inoue M, Tahara H, Kobayashi T, Takatsuka Y, Matsuvoshi N, Hirano S and Takeichi $\mathrm{M}$ : Expression of E-cadherin cell adhesion molecules in human breast cancer tissues and its relationship to metastasis. Cancer Res 53: 1696-1701, 1993.

22 Heimann R, Lan F, McBride R and Hellman S: Separating favorable from unfavorable prognostic markers in breast cancer: the role of E-cadherin. Canc Res 60(2): 298-304, 2000.

23 Bracke ME, Van Roy FM and Mareel MM: The E-cadherin/ catenin complex in invasion and metastasis. Cur Top Microbiol Immunol 213(Pt 1): 123-161, 1996.

24 Garcia del Muro X, Torregrosa A, Munoz J, Castellsague X, Condom E, Vigues F, Arance A, Fabra A and Germa JR: Prognostic value on the expression of E-cadherin and $B$-catenin in bladder cancer. Eur J Cancer 36(3): 357-362, 2000.

25 Detterbeck FC, Boffa DJ and Tanoue LT: The new lung cancer staging system. Chest 136(1): 260-271, 2009.

26 Tsoukalas N, Kostakis I, Siakavellas S, Giagnis C, Bournakis E, Sfiniadakis I, Karameris A, Patsouris E and Theocharis S: The clinical and pathological significance of RCAS1 expression as a prognostic biomarker in non-small cell lung cancer. In Vivo 28: 375-382, 2014

27 Voduc D, Kenney $\mathrm{C}$ and Nielsen TO: Tissue microarrays in clinical oncology. Semin Radiat Oncol 18: 89-97, 2008.

28 Camp RL, Neumeister V and Rimm DL: A decade of tissue microarrays: progress in the discovery and validation of cancer biomarkers. J Clin Oncol 26: 5630-5637, 2008.

29 Karlsson C, Bodin L, Piehl-Aulin K and Karlsson MG: Tissue microarray validation: a methodologic study with special reference to lung cancer. Cancer Epidemiol Biomarkers Prev 18: 2014-2021, 2009.

30 Schmidt LH, Biesterfeld S, Kummel A, Faldum A, Sebastian M, Taube C, Buhll R and Wiewrodt R: Tissue microarrays are reliable tools for the clinicopathological characterization of lung cancer tissue. Anticancer Res 29: 201-209, 2009.

31 Thomson S, Buck E, Petti F, Griffin G, Brown E, Ramnarine N, Iwata KK, Gibson N and Haley JD: Epithelial to mesenchymal transition is a determinant of sensitivity of non-small-cell lung carcinoma cell lines and xenografts to epidermal growth factor receptor inhibition. Cancer Res 65: 9455-9462, 2005.

32 Ngan CY,YamamotoH, Seshimo I,Tsujino T, Man-I M, Ikeda JI, Konishi K, Takemasa I, Ikeda M, Sekimoto M, Matsura N and Monden M: Quantitative evaluation of vimentin expression in tumour stroma of colorectal cancer. BrJ Cancer 96: 986-992, 2007.

33 Baumgart E, CohenMS, Silva Neto B, Jacons MA, Wotkowicz C, Rieger-Christ KM, Biolo A, Zeheb R, Loda M, Libertino JA and Summerhayes IC: Identification and prognostic significance of an epithelial-mesenchymal transition expression profile in human bladder tumors. Clin Cancer Res 13: 1685-1694, 2007.

34 MandalM, MyersJN, Lippman SM, Johnson FM, Williams MD, Rayala S, Ohshiro K, Rosenthal DI, Weber RS, Gallick GE and
El-Naggar AK: Epithelial to mesenchymal transition in head and neck squamous carcinoma: association of SRC activation with E-cadherin down-regulation, vimentin expression, and aggressive tumor features. Cancer 112: 2088-2100, 2008.

35 Vasko V, Espinosa AV, Scouten W, He H, Auer H, Liyanarachchi S, Larin A, Savchenko V, Francis GL, de la Chapele A, Saji M and Ringel MD: Gene expression and functional evidence of epithelialto-mesenchymal transition in papillary thyroid carcinoma invasion. Proc Natl Acad Sci USA 104: 2803-2808, 2007.

36 Pectasides E, Rampias T, Sasaki C, Perisanidis C, Kouloulias V, Burtness B, Zaramboukas T, Rimm D, Fountzilas G and Psyrri A: Markers of epithelial to mesenchymal transition in association with survival in head and neck squamous cell carcinoma (HNSCC). PLoS ONE 9(4): e94273, 2014.

37 Park SY, Lee HS, Jang HJ, Lee GK, Chung KY and Zo JI: Tumor necrosis as a prognostic factor for stage Ia non-small cell lung cancer. Ann Thorac Surg 91: 1668-1673, 2011.

38 Lang SH, Hyde C, Reid IN, Hitchcock IS, Hart CA, Bryden AA, Villette JM, Stower MJ and Maitland NJ: Enhanced expression of vimentin in motile prostate cell lines and in poorly differentiated and metastatic prostate carcinoma. Prostate 52: 253-263, 2001.

39 Yamanda S, Fuchs B, Fujii T, Shimoyama Y, Sugimoto H, Nomoto S, Takeda S, Tanabe K, Kodera $\mathrm{Y}$ and Nakao A: Epithelial-to-mesenchymal transition predicts prognosis of pancreatic cancer. Surgery 154(5): 946-954, 2013.

40 Liu T, Zhang X, Shang M, Zhang Y, Xia B, Niu M, Liu Y and Pang D: Dysregulated expression of Slug, vimentin, and Ecadherin correlates with poor clinical outcome in patients with basal-like breast cancer. J Surg Oncol 107(2): 188-194, 2013.

41 Shiels M, Pfeiffer RM, Hildesheim A, Engels E, Kemp T, Park JH, Katki HA, Koshiol J, Shelton G, Capotaso N, Pinto LA and Chaturvedi A: Circulating inflammation markers and prospective risk for lung cancer. J Natl Cancer Inst 105(24): 1871-1880, 2013.

42 Pacurari M, Addison J, Bondalapatti N, Wan YW, Luo D, Qian Y, Castranova A, Ivanov A and Guo NL: The microRNA-200 family targets multiple non-small cell lung cancer prognostic markers in H1299 cells and BEAS-2B cells. Int J Oncol 43: 548560, 2013.

43 . Hu Q, Ping X, Li J and Yu P:A retrospective analysis of serum tumor markers found in non-small cell lung cancer. J Cancer Res Ther 12(1): 117-120, 2016.

44 Jakobsen KR, Demuth C, Sorensen BS and Nielsen AL: The role of epithelial to mesenchymal transition in resistance to epidermal growth factor receptor tyrosine kinase inhibitors in non-small cell lung cancer. Transl Lung Cancer Res 5(2): 172-182, 2016.

45 Gower A, Hsu WH, Hsu ST, Wang Y and Giaccone G:EMT is associated with, but does not drive resistance to ALK inhibitors among EML4-ALK non-small cell lung cancer. Mol Oncol 10(4): 601-609, 2016.

46 Zhao Q, Gu X, Zhang C, Lu Q, Chen H and Xu L: Blocking M2 muscarinic receptor signaling inhibits tumor growth and reverses epithelial-mesenchymal transition (EMT) in non-small cell lung cancer (NSCLC). Cancer Biol Ther 16(4): 634-643, 2015.

Received February 16, 2017 Revised March 20, 2017 Accepted March 21, 2017 